\title{
AN ANALYSIS TO WOMEN AND CHILD WELFARE DEPARTMENT IN KOLHAPUR DISTRICT
}

\author{
Dr. Shashikant Subrao Sanghraj \\ Associate Professor,Department of Political Science,Dr. Ghali College, Gadhinglaj, \\ Dist. - Kolhapur. Maharashtra (India)
}

\section{INTRODUCTION}

Women and Child Welfare Departments 1991 have been established. In 1993, our government set up an independent department for the development of women and children. The Women and Child Welfare Center in Maharashtra take care of the helpless, sheltherless, dependent, homeless, deaf and dumb and abandoned. Women and nuns (Devdasi) also get help in this project. Through special planning they provide education, training and protection services and rehabilitation facilities.

Such problems and solutions are considered in this research. In this research, Kolhapur District Women and Child Welfare Program and its adverse effects have been analyzed with the above objective chosen by the researcher. Among total population of India, half population is of women's, nation's development is impossible without their development. Any country in the world can make progress by ignoring the power of women. We cannot make social, economic and political progress of the country without women. Today women have entered every field; they will be given the opportunity to go sour in their field. A number of projects have been launched for this purpose. Women empowerment is done through selfhelp groups. Before taking their progress in consideration, in the past how where their plight and how they achieve progress this is to be taken account. How these women enter in various fields? The journey of their struggle and plight to be pursuid and studied.

The Women's Welfare Department was established for the welfare and empowerment of
Article DOI: https://doi.org/10.36713/epra8170

DOI No: 10.36713/epra8170

women. To make women self-reliant and independent, for the progress of women this project has to take assistance of government sectors, non-government organizations and other institutions. These departments work together in coordination, with the responsibility of maintaining and implementing various programs. In the case of women, justice has events and problems around the world. The status of women is interior to that of men. In today's modern age every person is enjoying happiness and joy through material progress. But women for their social status, concern with great hope at laws made for them. UNO is working to bring new vigour to their lives.

Women and Child Welfare Committees have been set up to run various schemes in Municipal Corporations, Municipal Councils / Nagar Panchayats in the State. This committee has given information about the programs to be run with reference letters and to the entire corporation, council as per the government decision.

However, according to variable situation there is necessary to improve or change in the scheme because of several schemes has been outdated. As well as may be in the Corporation Council / Municipality there is an improper execution of women schemes because of lack of adequate financial provision.

\section{Definition of Women Empowerment}

1. According to the Grifen the empowerment of women means the ability of women to take decision, to implement it, to organize women 


\title{
EPRA International Journal of Research and Development (IJRD)
}

\author{
Volume: 6 | Issue: 8 | August 2021 \\ - Peer Reviewed Journal
}

to implement any activity such as public contact, financial transaction etc.

2. According to the Srilata Batliwala, "A wellknown women activist has defined women's empowerment as, "the process by which women gain greater control over the material and intellectual resources, and challenge the ideology of patriarchy and gender based discrimination against women in all institutions and structures of society."

\section{RESEARCH PROBLEM}

The current study is not intended to understand general social welfare or the development of increased productivity. But the aim is to understand the real reach of the social welfare program to the target beneficiaries, including orphans childern, neglected and deprived women. It would attempt to understand the reach of different development schemes to the actual beneficiaries in Kolhapur district which include professional training to deprived women, annual aids for diets, facilities at institutions like orphanages and protection houses, facilities of loans. The researcher will study whether the benefits of these schemes reach the target beneficiaries. It is an open truth that the implementation of welfare programs like girl education, health, healthy diet and other development schemes is not carried out to the desired extent to alleviate social problems. Therefore, needy women and their children have to face different problems.

\section{OBJECTIVES OF STUDY}

1. Analysis of allotted fund in women and children welfare of Kolhapur District.

2. Analysis of actual expenditure in women and children welfare of Kolhapur Municipal Corporation.

3. To suggest measures for improvement if necessary.

\section{RESEARCH METHODOLOGY}

Any research if necessary to methodology this research use only secondary data has been collected from Books, Journals, various years of socio-economic survey of Maharashtra, Annual Budgets, Annual Reports, and Official Records of the Kolhapur district for the period into consideration (2001 to 2018).

\section{LIMITATIONS} limitations

The present research study has the following

$>$ The study deals with only attempts of the Kolhapur district for women and children welfare.

$>$ The present study is limited to the period 2000-01 to 2017-18.

$>$ The present study considers only women and children welfare.

\section{$>$ Data Analysis and Interpretation}

After consideration above all these things government has been ordered to the entire Municipality, Council to develop women in all sectors.

1. Technical and Vocational Training for Women \& Girls.

2. To run a Nursery / to provide tools / help to institutes which run nursery.

3. Arrange the Training Trip about work and Scheme for Representatives of Women in Kindergarten (K.g).

4. Encourage Grant to stop proportion of School Leakage of Backward Girls.

5. To honor students who have got maximum marks in std.10th to std. 12th exams, this honors those students who are in under municipal area.

6. Scheme for Physical Development and Self Defense Protection of Girls.

7. Training of Yoga for Women.

8. To Create Sports facilities in Girls School.

9. To create Gardens for the children and Sport center for women.

10. Arrange competition for women and as well as children to encourage their skills.

11. Hostels for Needy Women.

12. Establish Sales Center to Sale Products of Women's Saving Group.

13. Run Counseling Center for Women.

14. Arranging a health care camp to medical check-up of girls and women.

15. To run a cleaning campaign in the region of backward and in slum area.

Women and Children welfare Committee has all the rights to select or chose schemes from the above schemes. 


\section{EPRA International Journal of Research and Development (IJRD)}

Table no. 1

Expenditure on Women and Child Welfare department by Kolhapur District

\begin{tabular}{|c|c|c|c|}
\hline Sr. No. & Year & Allotted Fund & Actual Expenditure \\
\hline 1 & 2001-02 & 20.00 & 0.25 \\
\hline 2 & $2002-03$ & 21.75 & 0.90 \\
\hline 3 & $2003-04$ & 40.85 & 3.13 \\
\hline 4 & 2004-05 & 38.22 & 0.25 \\
\hline 5 & $2005-06$ & 26.97 & 0.37 \\
\hline 6 & $2006-07$ & 27.10 & 2.99 \\
\hline 7 & 2007-08 & 34.10 & 1.20 \\
\hline 8 & 2008-09 & 40.00 & 7.91 \\
\hline 9 & $2009-10$ & 50.65 & 0.77 \\
\hline 10 & $2010-11$ & 70.00 & 29.48 \\
\hline 11 & 2011-12 & 70.75 & 17.13 \\
\hline 12 & $2012-13$ & 40.00 & 23.57 \\
\hline 13 & 2013-14 & 80.00 & 62.86 \\
\hline 14 & 2014-15 & 200.00 & 71.82 \\
\hline 15 & $2015-16$ & 200.00 & 74.79 \\
\hline 16 & $2016-17$ & 143.00 & 61.03 \\
\hline 17 & $2017-18$ & 152.92 & 66.18 \\
\hline \multicolumn{2}{|c|}{ Average } & 73.90 & 24.98 \\
\hline \multicolumn{2}{|c|}{ SD } & 61.08 & 29.58 \\
\hline \multicolumn{2}{|c|}{$\mathrm{CV}$} & 82.65 & 118.44 \\
\hline \multicolumn{2}{|c|}{ CAGR } & 0.14 & 0.42 \\
\hline \multicolumn{2}{|c|}{ Maximum } & 200 & 74.79 \\
\hline \multicolumn{2}{|c|}{ Minimum } & 20 & 0.25 \\
\hline
\end{tabular}

(Rs. In lakh)

Source: Socio-Economic Survey of Kolhapur District.

In this table no. 1 indicate that the expenditure on women and child welfare department by Kolhapur district. The average Kolhapur district under allotted fund in women and child welfare department during the period 2001-02 to 2017-18 was 73.90 lakh respectively. The coefficient of variance allotted fund in women and child welfare department was 82.65 percent respectively. It means that allotted fund in women and child welfare department is fluctuating than Kolhapur district area. The compound annual growth rate of allotted fund in women and child welfare department was 0.14 percent respectively. The maximum allotted fund in women and child welfare department has been observed as 200 lakh in 2014-15 and 2015-16 in this year. Likewise the minimum allotted fund in women and child welfare department has been observed as 20 lakh respectively during the study period. This table concluding to that during the period 2001-02 to 2017-18 allotted funds in women and child welfare department is fluctuating.

The average Kolhapur district under actual expenditure in women and child welfare department the period 2001-02 to 2017-18 was 24.98 lakh respectively. The coefficient of variance actual expenditure in women and child welfare department was 118.44 percent respectively. It means that actual expenditure in women and child welfare department is fluctuating than Kolhapur district area. The compound annual growth rate of actual expenditure in women and child welfare department was 0.42 percent respectively. The maximum actual expenditure in women and child welfare department has been observed as 74.79 lakh in 2015-16 this year. Likewise the minimum actual expenditure in women and child welfare department has been observed as 0.25 lakh respectively during the study period. This table concluding to that during the period 2001-02 to 2017-18 actual expenditure in women and child welfare department is fluctuating.

\section{CONCLUSIONS}

1. The average Kolhapur district under allotted fund in women and child welfare department during the period 2001-02 to 2017-18 was 73.90 lakh respectively. 


\section{EPRA International Journal of Research and Development (IJRD)}

Volume: 6 | Issue: 8 | August 2021

2. The coefficient of variance allotted fund in women and child welfare department was 82.65 percent respectively. It means that allotted fund in women and child welfare department is fluctuating than Kolhapur district area.

3. The compound annual growth rate of allotted fund in women and child welfare department was 0.14 percent respectively.

4. The maximum allotted fund in women and child welfare department has been observed as 200 lakh in 2014-15 and 2015-16 in this year. Likewise the minimum allotted fund in women and child welfare department has been observed as 20 lakh respectively during the study period. This table concluding to that during the period 200102 to 2017-18 allotted funds in women and child welfare department is fluctuating.

5. The average Kolhapur district under actual expenditure in women and child welfare department the period 2001-02 to 2017-18 was 24.98 lakh respectively.

6. The coefficient of variance actual expenditure in women and child welfare department was 118.44 percent respectively. It means that actual expenditure in women and child welfare department is fluctuating than Kolhapur district area.

7. The compound annual growth rate of actual expenditure in women and child welfare department was 0.42 percent respectively.

8. The maximum actual expenditure in women and child welfare department has been observed as 74.79 lakh in 2015-16 this year. Likewise the minimum actual expenditure in women and child welfare department has been observed as 0.25 lakh respectively during the study period. This table concluding to that during the period 200102 to 2017-18 actual expenditure in women and child welfare department is fluctuating.

\section{SUGGESTION}

1. Implementation of the government schemes is not transparent.

2. The government provides professional training to women. The government aid or scholarship given during the period of training is required to be increased.
- Peer Reviewed Journal

3. Detail information of women and child welfare department schemes should be given at Grampanchayat.

\section{REFERENCES}

1. Mulani M.U. (2012), "Self Help Groups \& Empowerment of Women", Manas Publication and Distributors, Jaipur, ISBN: 978-81-9217435-8, pp. 225.

2. Kamble P. S. (2001), "Finances of Kolhapur Municipal Corporation”, (Ph.D. Thesis), Shivaji University, Kolhapur.

3. More S. V. (2019), Women empowerment and self-help group in Kolhapur Municipal Corporation and Sangli-Miraj-Kupwad Municipal Corporation, (Ph.D. Thesis), Shivaji University, Kolhapur.

4. Kawre K. D., (2014), Analytical study of the impact of Government welfare scheme of women and child welfare department in Akola District, (Ph. D. Thesis), Shri Jagdish Prasad Jhabarmal Tibrewala University Vidyanagari, Jhunjhun, Rajasthan.

5. Joshi A. (2017), women and child welfare schemes in India and how media can promote outreach, International Journal of Current Innovation Research, Vol. 3, Issue 12, pp. 947954.

\section{WEBSITES}

1. www.kolhapurmunicipalcorporation.gov.in

2. www.shodhganga.ac.in 